\title{
Identification of Arboreal Vegetation and Potential Areas in the Commercial Center of Capitão Poço, Brazil
}

\author{
Washington Duarte Silva da Silva, Jordan Luis Campos Modesto Pereira, Milton Garcia \\ Costa, Adriane dos Santos Santos, Magda do Nascimento Farias, Ana Paula Souza Ferreira, \\ Luiz Carlos Pantoja Chuva de Abreu, Lucila Ferreira da Silva \\ Universidade Federal Rural da Amazônia, Brazil
}

Maria Thalia Lacerda Siqueira

Universidade Estadual Paulista "Júlio de Mesquita Filho", Brazil

Received: March 25, 2021 Accepted: May 20, 2021 Published: May 24, 2021

doi:10.5296/jas.v9i2.18446

URL: https://doi.org/10.5296/jas.v9i2.18446

\begin{abstract}
Green spaces are urban spaces that bring man and nature closer together, positively influencing the quality of life of the population. The planning of green spaces is essential in urban areas and Geographic Information Systems (GIS's) are tools capable of assisting in the identification, management and monitoring of these spaces. The objective of the work was to map the urban vegetation and carry out a survey of potential areas for parks and green areas in the commercial center from the municipality of Capitão Poço - PA. The study was carried out in the commercial center from Capitão Poço, PA - Brazil by obtaining images from the Google Earth software and photointerpreted with the aid of the QGIS software. Finally, the current and potential tree green areas were identified in the georeferenced images. The survey of green areas in the commercial center identified that only $4.74 \%$ of the total area contains tree vegetation, in addition to $53 \%$ of this vegetation being found around the mother church and the municipal square of Alvorada. For potential green areas, it was found that the commercial center has $5,873.5 \%$ more potential areas in relation to current tree vegetation. In this sense, it is observed that the commercial center from the municipality of Capitão Poço contains a low proportion of areas with arboreal vegetation and a high potential for the implantation of parks, forests and other types of green areas.
\end{abstract}

Keywords: urban environment, geographic information systems, urban afforestation, urban planning, green areas, geoprocessing, conservation 


\section{Introduction}

The growing demand for occupation of spaces in the urban environment due to the high population increase, has led cities to increasingly seek to optimize spaces, changing the natural and anthropic environment. Changing this urban environment is directly linked to climate change, causing damage to the well-being of the local population (Labaki et al., 2011). The losses faced with the drastic transformation of the natural environment are linked to air and water pollution, floods, excessive noise, increased temperatures and other problems that cause serious damage to the physical and psychological health of the population (M'Ikiugu et al., 2012).

The population increase and expansion of the built-up areas of the cities and added to the lack of effective public policies in environmental management generate the misuse and pollution of natural resources, causing the reduction of vegetation, to the detriment of the expansion of the built-up areas and the market action. causing a disorderly growth of cities. For Bargos (2010), it is common for environmental problems to be associated with the ways in which man produces this place in order to guarantee his conditions of survival.

Among the benefits promoted by urban afforestation, many are linked to trees, since improvements to the environment and environmental balance directly contribute to social development and guaranteeing a better quality of life for the population (Barbosa et al., 2015). Vegetation plays an essential role in urban centers, improving the environment through the ability to produce shade, filter out noise, mitigating noise pollution; improve air quality, and perform the absorption of carbon dioxide; softens the temperature, among other functions (Vieira et al., 2018). And yet, it contributes to leisure and well-being for the population, in addition to the aesthetics of the place and the economic valuation of urban areas and, finally, living conditions in the urban environment (Graziano, 1994).

Green parks develop an important role for social comfort, providing the development of sports, recreational and leisure activities. In this sense, green parks encourage the population to perform physical activities and contribute to a higher quality of life of the population. On the other hand, poor environmental quality and user dissatisfaction are the negative environmental determinants for the use of the park, in order to disfigure these functions associated with quality of life and public health. (Szeremeta and Zannin, 2009).

There is a need for public policies that encourage the construction and revitalization of green spaces in the urban environment, since these spaces are equally important in relation to other public spaces. However, it is necessary to actively perceive potential areas so that people feel attracted and motivated to participate in these environments and to enjoy their benefits in a satisfactory way (Reis, 2001).

Geographic Information Systems (GIS's) are important tools for obtaining information and detailing the results, such as essential data for better planning of urban planning and for defining intervention priorities, in addition to minimizing data collection costs (Shahtahmassebi et al., 2021). And yet, it makes it possible to plan, monitor and manage or even create a database specific to urban vegetation and its specialization through thematic 


\section{Ml Macrothink}

maps and associated cadastral plants (Souza et al., 2012).

The objective of the work was to map the urban vegetation and carry out a survey of potential areas for parks and green areas in the commercial center from the municipality of Capitão Poço - PA.

\section{Method}

\subsection{Location and Characterization of the Study Area}

The study area consisted from the municipality of Capitão Poço - PA, comprised between the geographical coordinates $1^{\circ} 44^{\prime} 45^{\prime} \mathrm{S}$ and $47^{\circ} 03$ '34" W (Figure 1). Currently, the municipality has an estimated population of 52,831 inhabitants in an area of approximately 2,899,532 km2, according to census data from IBGE (2010).
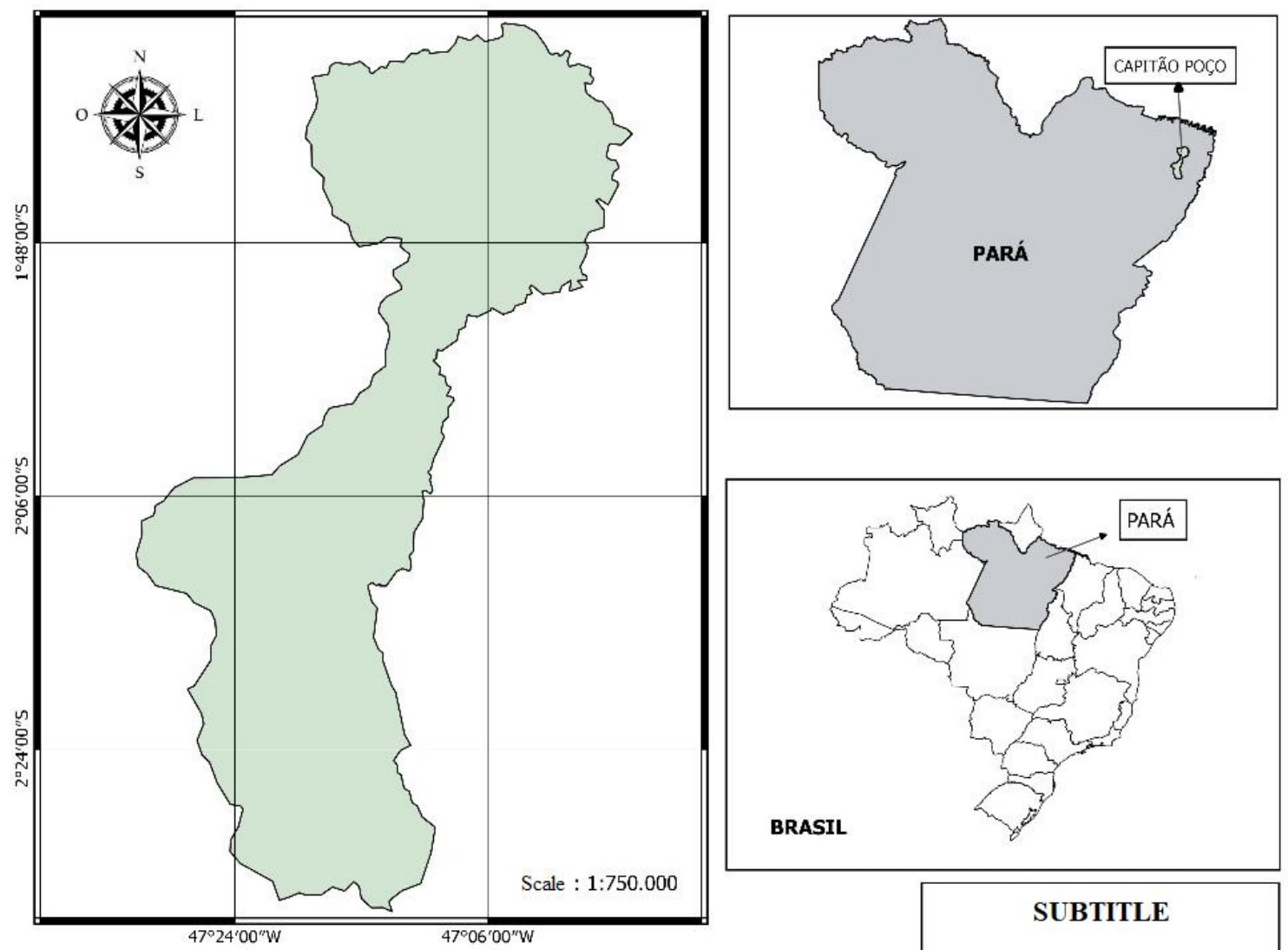

BRASIL

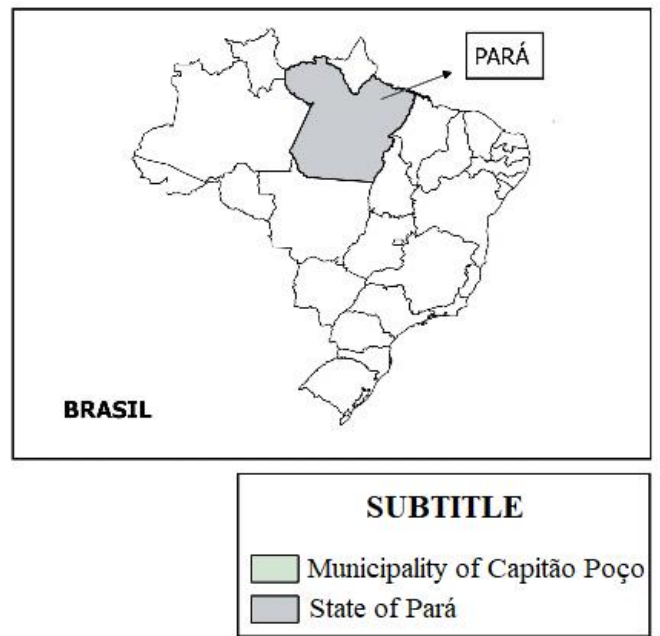

Figure 1. Location of the study area in the municipality of Capitão Poço - PA

According to Pacheco and Bastos (2002), the municipality of Capitão Poço is classified as tropical, falling under the climatic type Am, of the Koppen classification, characterized as rainy or without seasonal winter, presenting a small dry season. The average temperature from the municipality is $26.1^{\circ} \mathrm{C}$ and the annual rainfall is $2,256 \mathrm{~mm}$ (Pacheco and Bastos, 2002). 


\subsection{Image Processing and Photointerpretation}

The images from the municipality of Capitão Poço were obtained in JPEG format, using the Google Earth software, for the visual analysis of the conditions of areas with potential for possible green parks and vegetation in the perimeter of the commercial center. The images made available by Google Earth for the Capitão Poço region date from June 13, 2018 and come from the CNES / Airbus satellite, whose spatial resolution reaches 50 centimeters in panchromatic images and 2 meters from blue to near infrared (Embrapa, 2013). In the images, four points were marked, so that the coordinates were known. Thus, the images in the $4800 \mathrm{x}$ 2843 raster format were saved for photointerpretation in the QGIS software.

In the QGIS software, the image was georeferenced, using the coordinates known and selected in Google Earth. Subsequently, a shapefile layer was defined, delimiting the central area of the urban area from Capitão Poço - PA, since the commercial center is located. Within the study area, a new layer of polygon shapefile was created, demarcating all the tree vegetation. Finally, we sought to delimit areas that have the potential to become possible parks or green areas. Potential areas for parks or local green areas not built with dimensions greater than $5,000 \mathrm{~m}^{2}$ were considered. After identifying the potential areas, they were plotted and their dimensions were measured in the image.

\section{Results and Discussion}

3.1 Mapping and Quantification of Vegetation in the Central Area From Capitão Poço - PA, Brazil

134 polygons identified as an area of tree vegetation distributed in the area delimited for the survey (Figure 2). This number corresponds to a total area of $22,958 \mathrm{~m}^{2}$ of tree vegetation, representing approximately $0.8 \%$ of the total area from Capitão Poço and $4.7 \%$ commercial center area in 2018 (Table 1). According to Bobrowsk (2015), afforestation encompasses multiple benefits, which are environmental, aesthetic, economic and psychosocial. In 2010, the municipality from Capitão Poço had a rate of afforestation of public roads of $32.5 \%$ (Ibge, 2010). However, it appears that the municipality has reduced the rate of afforestation in recent years, indicating the need for public policies that can stimulate and increase this index.

Among the ecological benefits provided by vegetation, one of the most important, involves improving the urban microclimate, where vegetation causes changes in the temperature of the place, in addition to increasing the relative humidity and decreasing direct solar radiation, providing shaded places (Rossetti et al., 2010). In terms of economic and political value, urban forests increase real estate speculation and play an important role in promoting urban development (Biondi and Althaus, 2005).

The place that presented the most arboreal prominence was around the Mother Church of the municipality with $8,586.93 \mathrm{~m}^{2}$, representing $0.3 \%$ of the total area and $1.77 \%$ of the commercial center. Such fact may be related to the afforestation in the main church square, in addition to the central flowerbeds of the street surrounding it. According to Souza et al. (2010), the quality of life in the city is related to the planned afforestation, among other factors that aim to promote the interrelationship between social, artificial (anthropized) and green space. In this sense, urban afforestation is able to add liveliness and enhance public 


\section{MInstitute ${ }^{\text {Mink }}$}

roads (Maria and Cavalcante, 2021).

The municipal square, named Alvorada, shows that a significant part comprises around it, with $3,685.95 \mathrm{~m}^{2}$, representing $0.13 \%$ of the total area and $0.76 \%$ of the study area. From this perspective, it appears that the municipal square is a place with a large number of visitors, noting that there is a need for more adequate planning for the better use of space, giving preference to the natural component instead of built environments, such as the concrete. According to Lustosa Filho et al. (2016), urban planning must have a comprehensive plan of afforestation, mainly including species native to the region, as these species can preserve the biological characteristics of the area, in addition to their preservation and conservation.

For the areas around the banks of the river that runs through the municipality's commercial center, they do not have adequate preservation, as it is at odds with the provisions of Article 4 of the Brazilian Forest Code - Law 12.727 / 2012 (Brasil, 2012). Since it determines that the size of the permanent preservation area (PPA) must occupy 30, 50, 100, 200 and $500 \mathrm{~m}$ for water courses smaller than 10,20, 200, 600 and greater than $600 \mathrm{~m}$. width, respectively. The tree vegetation on the banks of the river occupies only $0.67 \%$, which is about $3,242.48 \mathrm{~m}^{2}$, much less than what the PPA should cover.

According to Cecchetto et al. (2014), trees were more present in urban centers and in the composition of the city itself, however with the unrestrained population growth and without planning these trees ended up being subtracted. Result of an uncontrolled urban growth, the same situation is found in Capitão Poço, where most of the city grew up around the natural water courses, deforesting its area of permanent preservation.

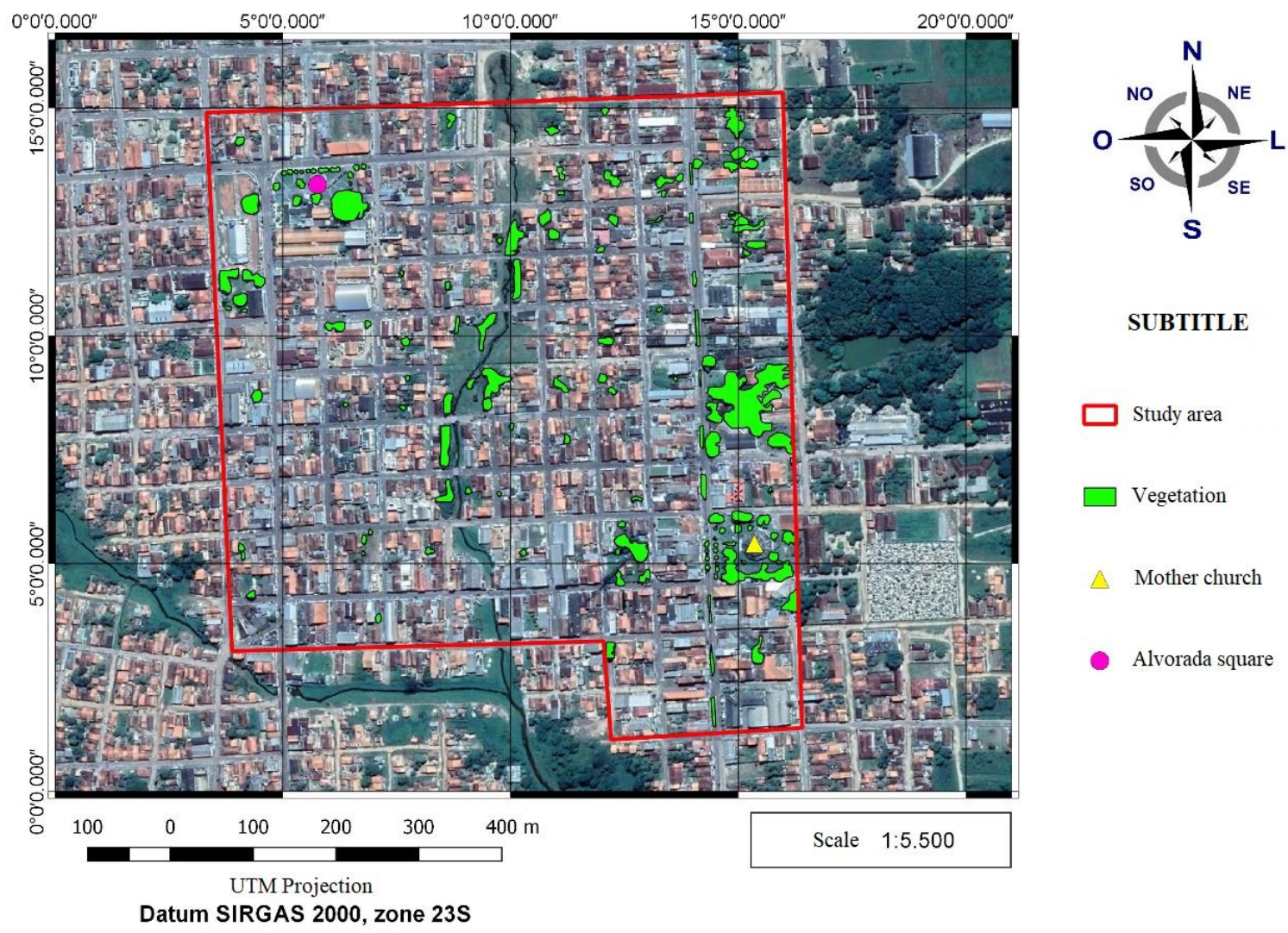

Figure 2. Mapping of tree vegetation in the central area from Capitão Poço - PA 
Table 1. Quantification and percentages of the vegetation class in relation to the total area and the commercial center of the municipality of Capitão Poço, PA

\begin{tabular}{|c|c|c|c|}
\hline \multirow[b]{2}{*}{ Class } & \multirow[b]{2}{*}{ Area $\left(m^{2}\right)$} & \multicolumn{2}{|c|}{ Percentual $(\%)^{*}$} \\
\hline & & $\begin{array}{c}\text { Total area of the } \\
\text { municipality }\end{array}$ & $\begin{array}{c}\text { Commercial } \\
\text { center area }\end{array}$ \\
\hline Tree vegetation & 22,958 & 0.79 & 4.74 \\
\hline Surrounding the Mother Church & $8,586.93$ & 0.30 & 1.77 \\
\hline Surrounding the Praça da Alvorada & $3,685.95$ & 0.13 & 0.76 \\
\hline River banks & $3,242.48$ & 0.11 & 0.67 \\
\hline
\end{tabular}

Note. The percentages were obtained from the quotient of the area of tree vegetation and total area and the quotient of the area of tree vegetation and commercial area of the municipality.

\subsection{Mapping of Potential Areas for Possible Parks and Green Areas}

The areas surrounding the streams (A1, A2, A3 and A4) that run through the commercial center stand out positively to become parks or green areas, as they currently have a low tree presence (Figure 3). When comparing the potential areas for parks and green areas, it appears that they are $5,873.5 \%$ higher than the current tree vegetation of the commercial center. This fact indicates the potential for green areas and parks that the municipality has, but it needs public policies to increase these areas.

Aiming its vast territory, strategic location in the urban area of the city and in order to recover the riparian forests, the creation of a project to install the green park may prevent the progress of the silting up of rivers and the growth of urban centers around the banks of water courses. The A5 area is a place with a large amount of vegetation, however it is a private property, which prevents free access for the population.

According to Silva (2003), the urban green park emerged with the objective of providing enough space for the city to meet new social needs: like leisure, in sharp contrast to the busy urban environment. With green spaces specially to improve people's living standards in an urban environment.

Urban afforestation is important for the performance of ecological, historical, cultural, social, aesthetic and landscape activities. However, for there to be green spaces, it is necessary to establish policies and an excellent planning for the implantation and preservation of these environments (Cecchetto et al., 2014). Thus, there is a lack of a public policy program in the municipality that promotes the valorization of nature, given that there is idle space in the urban center to develop works related to the creation of green spaces, as it is possible to identify in the present work (Figure 3). Such demands are justified by Melo and Romanni (2007), stating that the growth of green spaces must be directly proportional to the growth of the city so that they can offer ideal conditions for residents and provide leisure and well-being for inhabitants. 


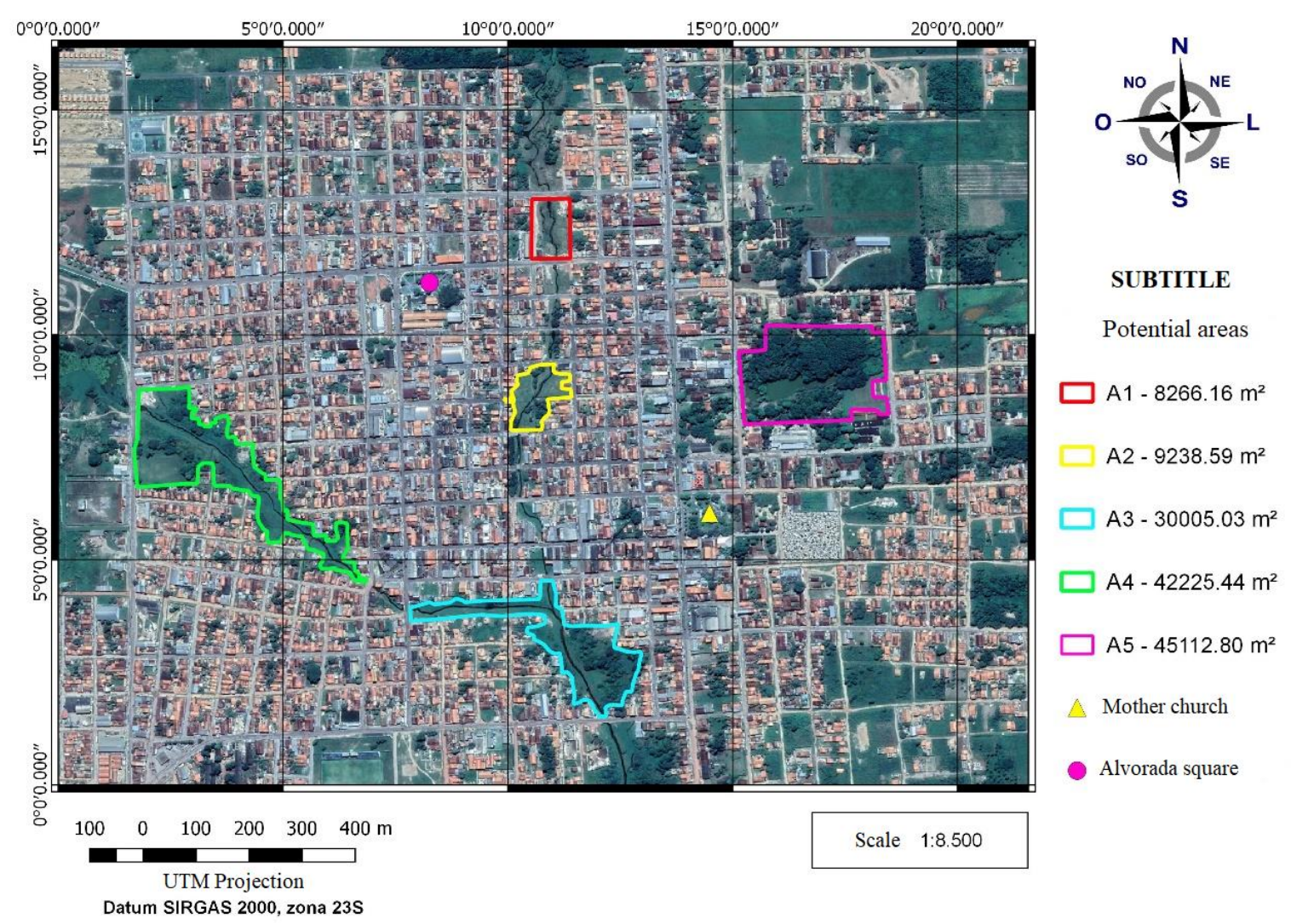

Figure 3. Areas with potential for parks and green areas

\section{Conclusions}

- The municipality of Capitão Poço has a low rate of tree vegetation in the commercial center, indicating the lack of public policies aimed at urban afforestation;

- The tree vegetation in the municipality of Capitão Poço is concentrated and poorly distributed, being around the mother church and in the municipal square of Alvorada;

- The municipality of Capitão Poço has high potential for green areas and the creation of parks, presenting areas for green spaces above the current tree vegetation of the commercial center.

\section{References}

Barbosa, R. P., Portela, M. G. T., Machado, R. R. B., \& Sá, A. S. (2015). Arborização da avenida Deputado Ulisses Guimarães, bairro Promorar, zona sul de Teresina - PI. Revista da Sociedade Brasileira de Arborização Urbana, 10(2), 78-89. https://doi.org/10.5380/revsbau.v10i2.63132

Bargos, D. C. (2010). Mapeamento e Análise das Áreas Verdes Urbanas como Indicador da Qualidade Ambiental Urbana: estudo de caso de Paulínia-SP. Dissertação (Mestrado em Geografia) - Instituto de Geociência da Universidade Estadual de Campinas, São Paulo.

Biondi, D., \& Althaus, M. (2005). Árvores de Rua de Curitiba: cultivo e manejo. Curitiba: FUPEF.

Bobrowski, R., \& Biondi, D. (2015). Influência das espécies exóticas invasoras na expressão 
da diversidade da arborização de ruas de Curitiba-PR. Revista da Sociedade Brasileira de Arborização Urbana, 10(2), 27-39. https://doi.org/10.5380/revsbau.v10i2.63242

Cecchetto, C. T., Christmann, S. S., \& Oliveira, T. D. de. (2014). Arborização urbana: importância e benefícios no planejamento ambiental das cidades. Anais. XVI Seminário Internacional de Educação no Mercosul. Cruz Alta, RS.

Embrapa/Satélites/Pléiades/Pléiades Satellite constellation. Available in: https://www.cnpm.embrapa.br/projetos/sat/conteudo/missao_pleiades.html. Access in: 22 ago. 2018 .

Graziano, T. T. (1994). Viveiros Municipais. FCAVJ: UNESP.

IBGE. Cidades@. (2010). Available in: https://cidades.ibge.gov.br/brasil/ pa/capitao-poco/panorama. Access in: 16 mar. 2021

Labaki, L. C., Santos, R. F. dos; Bueno-Bartholomei, C. L., \& Abreu-Harbich, L. V. de. (2011). Vegetação e conforto térmico em espaços urbanos abertos. Fórum Patrimônio, 4(1), $1-18$.

Lustosa Filho, D., Clementino, G. E. dos S., Costa, T. G. A., Serpa, L. do N., \& Iwata, B. de F. (2016). Inventário quali-quantitativo da arborização da avenida Adolfo John Tierry no município de Corrente-PI. In: Anais do Congresso Brasileiro de Gestão Ambiental e Sustentabilidade, 4(1), 355-362.

M'Ikiugu, M. M., Kinoshita, I., \& Tashiro, Y. (2012). Urban green space analysis and identification of its potential expansion areas. Procedia-Social and Behavioral Sciences, 35, 449-458. https://doi.org/10.1016/j.sbspro.2012.02.110

Maria, R., Cavalcante, D. B. (2018). A arborização como instrumento de políticas urbanísticas. p. 6-8. Available in: https://jus.com.br/imprimir/56243/aarborizacao-comoinstrumento-de-politicasurbanisticas. Access in: 14 mar. 2021.

Melo, E. F. R. Q., Romanini, A. (2007). A gestão da arborização urbana na cidade de Passo Fundo/RS. Revista da Sociedade Brasileira de Arborização Urbana, 2(1), 1-16. https://doi.org/10.5380/revsbau.v2i1.66227

Pacheco, N. A., \& Bastos, T. (2002). Análise frequêncial da chuva em Capitão Poço, PA. Belém: Embrapa Amazônia Oriental.

Reis, R. S. (2001). Determinantes Ambientais para a Realização de Atividades Físicas nosParques urbanos de Curitiba: Uma Abordagem Sócio Ecológica da Percepção dos Usuários. Dissertação (Mestrado em Educação Física) - Centro de Desportos da Universidade Federal de Santa Catarina, Florianópolis.

Rossetti, A. I. N., Pellegrino, P. R. M., \& Tavares, A. R. (2010). As árvores e suas interfaces no ambiente urbano. Revista da Sociedade Brasileira de Arborização Urbana, 5(1), 1-24. https://doi.org/10.5380/revsbau.v5i1.66231

Shahtahmassebi, A., Li, C., Fan, Y., Wu, Y., Gan, M., Wang, K., ... \& Blackburn, A. (2021). 
Remote sensing of urban green spaces: a review. Urban Forestry \& Urban Greening, 57, e126946. https://doi.org/10.1016/j.ufug.2020.126946

Silva, L. J. M. (2003). Parques urbanos: a natureza na cidade: uma análise da percepção dos atores urbanos. Dissertação (Mestrado em Desenvolvimento Sustentado). UNB Centro de Desenvolvimento Sustentado, Brasília.

Souza, A. M., Nachtergaele, M. F., \& Carboni, M. (2010). Inventário da Arborização Urbana do Município de Jaú/SP. Instituto Pró-terra: Jaú, SP.

Souza, S. M. de. (2012). Mapeamento da vegetação urbana da cidade de Vitória-ES. Geotecnologia aplicada aos recursos florestais. Alegre - ES.

Szeremeta, B., \& Zannin, P. H. T. (2009). Analysis and evaluation of sound scapes in public parks through interviews and measurement of noise. Science of Total Environment, 497, 6143-6149. https://doi.org/10.1016/j.scitotenv.2009.08.039

Vieira, J., Matos, P., Mexia, T., Silva, P., Lopes, N., Freitas, C., ... Pinho, P. (2018). Green spaces are not all the same for the provision of air purification and climate regulation services: The case of urban parks. Environmental Research, 160, 306-313. https://doi.org/10.1016/j.envres.2017.10.006

\section{Copyright Disclaimer}

Copyright for this article is retained by the author(s), with first publication rights granted to the journal.

This is an open-access article distributed under the terms and conditions of the Creative Commons Attribution license (http://creativecommons.org/licenses/by/4.0/). 